\title{
DAMPAK SERTIFIKASI GURU TERHADAP KUALITAS PENDIDIKAN PADA MADRASAH ALIYAH DI KOTA KENDARI
}

\section{The Impacts of Teacher Certification Toward The Education Quality at Islamic Senior High Schools in Kendari}

\author{
Asnandar Abubakar \\ Balai Penelitian dan Pengembangan Agama Makassar \\ Jl. AP. Pettarani No. 72 Makassar 90222 \\ Email: d410.4j4@gmail.com
}

Naskah diterima tanggal 12 Oktober 2014. Naskah direvisi tanggal 9 Maret 2015. Naskah disetujui tanggal 22 Mei 2015

\begin{abstract}
Abstrak
Penelitian ini dilakukan untuk mengetahui dampak sertifikasi guru terhadap kualitas pendidikan pada madrasah aliyah yang ada di Kota Kendari. Dengan tersertifikasinya guru diharapkan kompetensi yang dimiliki juga dapat meningkat dalam memenuhi tugasnya memberikan kualitas pengajaran yang baik. Peningkatan kompetensi guru baik kompetensi pedagogik, kompetensi professional, kompetensi kepribadian maupun kompetensi sosial diharapkan juga berdampak pada peningkatan kualitas madrasah aliyah. Penilaian dampak sertifikasi guru terhadap peningkatan kualitas madrasah dilihat dari aspek perencanaan program madrasah, pelaksanaan rencana kerja madrasah, peningkatan proses pembelajaran, peningkatan kompetensi sesama guru, dan pemanfaatan tunjangan sertifikasi. Jenis penelitian adalah penelitian kuantitatif yang bersifat survey yaitu mengumpulkan data dengan menggunakan angket yang berisikan kuisioner sebagai instrumen utama. Data ini kemudian dianalisis secara deskriptif yang telah dikategorikan dalam skala linkert untuk mengetahui sejauhmana keterlibatan guru yang telah tersertifikasi pada proses peningkatan kualitas madrasah aliyah.
\end{abstract}

Kata kunci: dampak sertifikasi, kualitas madrasah, sertifikasi guru

\begin{abstract}
This research was conducted to identify the impacts of teacher certification to education quality at Islamic Senior High Schools in Kendari. Through the certification, the teachers are expected to improve their competency in carrying out the duties to provide qualified teaching. The increase of teachers' competence in pedagogical competence, professional competence, personal competence and social competence is expected to also have an impact on improving the quality of Islamic senior high schools. The assessment of impact of teacher certification toward quality improvement of schools can be seen from the aspects of school program plan, the implementation of school work plan, the increase of teaching and learning process, the competence improvement of fellow teachers, and the utilization of certification allowance. The research is a quantitative method that is a survey that collected data by using questionnaires as the main instrument. The data were then analyzed descriptively which categorized them in linkert scale to determine the extent of involvement of certified teachers in the process of improving the quality of Islamic senior high schools.
\end{abstract}

Keywods: the impacts of certification, the quality of Islamic senior high schools, teacher certification

\section{PENDAHULUAN}

$\mathrm{K}$

edudukan guru sebagai pendidik profesional secara implisit disebutkan dalam UndangUndang Nomor 20 Tahun 2003 tentang

Sistem Pendidikan Nasional, begitupun juga dalam Undang-Undang Nomor 14 Tahun 2005 tentang Guru dan Dosen, Peraturan Pemerintah Nomor 19 Tahun 2005 tentang Standar Nasional Pendidikan serta Peraturan Pemerintah Nomor 
74 Tahun 2008 tentang Guru, bahwa guru adalah pendidik profesional dengan diberikan tugas utama mendidik, mengajar, membimbing, mengarahkan, melatih, menilai, dan mengevaluasi peserta didik pada usia dini jalur pendidikan formal, pendidikan dasar, dan pendidikan menengah. Guru profesional dituntut memiliki kualifikasi akademik minimum sarjana (S1) atau diploma (D-IV), menguasai kompetensi (pedagogik, profesional, sosial dan kepribadian), memiliki sertifikasi pendidik, sehat jasmani dan rohani, serta memiliki kemampuan untuk mewujudkan tujuan pendidikan nasional.

Guru yang dimaksud meliputi guru kelas, guru mata pelajaran, dan guru bimbingan dan konseling atau konselor. Sertifikasi adalah pemberian sertifikat pendidik melalui suatu proses yang sistematik sebagai pengakuan terhadap guru sebagai pendidik profesional.

Sertifikasi bagi guru dalam jabatan sebagai salah satu upaya peningkatan mutu guru diharapkan dapat meningkatkan mutu pendidikan pada satuan pendidikan formal secara berkelanjutan. Guru dalam jabatan yang telah memenuhi persyaratan dapat mengikuti sertifikasi melalui: (1) pemberian sertifikat pendidik secara langsung (PSPL), (2) portofolio (PF), (3) pendidikan dan pelatihan profesi guru (PLPG), atau (4) pendidikan profesi guru (PPG) (Buku 4, Kemendikbud, 2013).

Dalam memenuhi regulasi tersebut, pemerintah telah melakukan berbagai upaya dalam rangka peningkatan profesionalisme guru menuju peningkatan kualitas sekolah. Sejauh ini Kementerian Agama telah mengalokasikan anggaran biaya sertifikasi guru. Biaya tersebut digunakan untuk penghitungan portofolio dan PLPG. Pada tahun 2011 Direktorat Madrasah Kementerian Agama telah menyertifikasi sejumlah 38.000 pengawas dan guru madrasah melalui PSPL sementara sertifikasi guru dalam jabatan melalui jalur pendidikan sejumlah 2.400 orang. Dan pada tahun 2012 Direktorat Madrasah telah menyertifikasi sejumlah 2.400 orang guru agama melalui jaur pendidikan (http://pendis.kemenag. go.id).

Selain itu, dalam rangka peningkatan mutu dan kompetensi guru madrasah, Kementerian Agama melanjutkan kegiatan sertifikasi bagi guru serta mempercepat dan mengefektifkan penyelenggaraan kegiatan dimaksud dengan mengeluarkan Daftar Urut Prioritas (Long List) Calon Peserta Sertifikasi Bagi Guru RA/Madrasah Dalam Jabatan Untuk Mata Pelajaran Keagamaan (Quran Hadits, Akidah
Akhlak, Fiqh, SKI), Bahasa Arab, Guru Kelas RA, Guru Kelas MI dan Guru Mata Pelajaran Umum Tahun 2013 (http://madrasah.kemenag.go.id).

Kementerian Agama Republik Indonesia (RI) melalui Badan Litbang dan Diklat telah melakukan penelitian yang berhubungan dengan sertifikasi guru yaitu diantaranya tentang unit cost sertifikasi guru di tujuh propinsi di Indonesia. Penelitian ini bertujuan untuk memetakan kebutuhan pembiayaan sertifikasi guru madrasah dan guru Pendidikan Agama Islam (PAI) di sekolah di berbagai daerah dan melacak kebutuhan pembiayaan pada semua institusi yang terlibat layanan sertifikasi, yaitu meliputi Kementerian Agama (Kemenag) kabupaten/kota dan Kemenag Provinsi. Penelitan yang dilakukan di pulau Jawa, Kalimantan, NTT, Sumatera, dan Maluku menemukan bahwa pelayanan sertifikasi di Kemenag Kab/kota perlu dibiayai karena kegiatan layanan sertifikasi di Kemenag Kab/Kota cukup menyita perhatian dan tenaga staf bidang madrasah dan pendidikan agama (mapenda). Namun dari layanan ekstra tersebut, sejauh ini tidak ada dana khusus untuk mengawal kegiatan sertifikasi tersebut. Akibat dari ketiadaan dana ini di beberapa daerah, untuk memperlancar layanan sertifikasi beberapa mapenda Kemenag kab/kota mengusahakan uang administrasi kepada guru/peserta sertifikasi (http:// balitbangdiklat.kemenag.go.id/).

Dari sejumlah informasi tersebut, menggambarkan bahwa pelaksanaan program sertifikasi guru masih belum memberikan dampaknya secara maksimal terhadap peningkatan kualitas pendidikan secara umum. Olehnya itu, evaluasi kualitas pendidikan (satuan pendidikan) masih perlu dilakukan untuk memberikan informasi kepada pemerintah tentang keberhasilan sertifikasi guru. Dan atas dasar itu, perlu dilakukan proses penilaian dengan mengamati dampak guru tersertifikasi terhadap peningkatan kualitas pendidikan, khususnya dalam pengembangan budaya akademik di madrasah: perencanaan, proses, dan evaluasi pembelajaran, peningkatan prestasi siswa baik akademik, non akademik, maupun moral, peningkatan pengelolaan satuan pendidikan, khsususnya madrasah, sampai pada peningkatan citra kualitas dan minat masyarakat bersekolah di madrasah.

Masalah penelitian ini adalah, bagaimana dampak sertifikasi guru terhadap peningkatan kualitas pendidikan di madrasah? Pertanyaan penelitian adalah: Bagaimana dampak sertifikasi guru terhadap perencanaan progam madrasah, pelaksanaan rencana kerja madrasah, peningkatan 
proses pembelajaran, peningkatan kualitas sesama guru, dan pemanfaatan tunjangan sertifikasi.

Penelitian ini bertujuan untuk mengetahui interaksi (sumbangsi saran dan/atau tenaga) guru yang telah disertifikasi dengan komunitas madrasah dalam upaya meningkatkan kualitas pendidikan sebagai dampak status sertifikasi yang dimilikinya. Dampak terhadap kualitas pendidikan di madrasah dimaksud, mencakup: pengelolaan madrasah (perencanaan program dan pelaksanaan rencana kerja), peningkatan proses pembelajaran, peningkatan kualitas sesama guru, dan pemanfaatan tunjangan sertifikasi.

Penelitian diharapkan dapat bermanfaat teoritis terhadap peningkatan fenomena ilmu pendidikan, khususnya terhadap pengelolaan pendidikan keagamaan, dan diharapkan dapat bermanfaat praktis terhadap kebijakan Kementerian Agama Republik Indonesia dalam meningkatakan kualitas guru madrasah.

\section{Tinjauan Pustaka Sertifikasi Guru}

Denim (2002) dalam Suprihatiningrum (2013: 215) menjelaskan bahwa sertifikasi (sertification) mengandung makna, jika hasil penelitian atas persyaratan pendaftaran yang diajukan calon penyandang profesi dipandang memenuhi persyaratan, kepadanya diberikan pengakuan oleh Negara atas kemampuan dan keterampilan yang dimilikinya. Bentuk pengakuan tersebut adalah pemberian sertifikat kepada penyandang profesi tertentu, yang di dalamnya memuat penjelasan tentang kemampuan dan keterampilan yang dimiliki oleh pemegangnya.

Dalam Suyatno (2007: 2) disebutkan bahwa sertifikat adalah dokumen resmi yang menyatakan informasi di dalam dokumen itu benar adanya. Sertifikasi adalah proses pembuatan dan pemberian dokumen tersebut. Guru yang telah mendapat sertifikat berarti telah mempunyai kualifikasi mengajar seperti yang dijelaskan di dalam sertifikat itu.

Jadi sertifikasi guru adalah proses pemberian sertifikat pendidik kepada guru. Sertifikat pendidikan diberikan kepada guru yang telah memenuhi standar profesional guru. Guru profesional merupakan syarat mutlak untuk menciptakan sistem dan praktik pendidikan yang berkualitas (Shoimin, 2013: 81).

Sertifikasi guru juga dapat diartikan sebagai suatu proses pemberian pengakuan bahwa seseorang telah memiliki kompetensi untuk melaksanakan pelayanan pendidikan pada satuan pendidikan tertentu, setelah lulus uji kompetensi yang diselenggarakan oleh lembaga sertifikasi. Dengan kata lain, sertifikasi guru adalah proses uji kompetensi yang dirancang untuk mengungkapkan penguasaan kompetensi seseorang sebagai landasan pemberian sertifikat pendidik. National Commission on Educational Services (NCES) memberikan pengertian sertifikasi secara umum. Certification is a procedure whereby the state evaluates and reviews a teacher candidate's credentials and provides him or her a license to teach. Dalam hal ini sertifikasi merupakan prosedur untuk menentukan apakah seorang caon guru layak izin dan kewenangan untuk mengajar (Mulyasa, 2012: 34-35).

Dalam Undang-Undang Nomor 14 Tahun 2005 tentang Guru dan Dosen pasal 1 ayat 11 dan 12 serta Peraturan Pemerintah RI Nomor 74 Tahun 2008 tentang Guru, pada pasal 1 ayat 3 dan 4 disebutkan bahwa sertifikasi adalah proses pemberian sertifikat pendidik untuk guru. Sertifikat pendidik adalah bukti formal sebagai pengakuan yang diberikan kepada guru sebagai tenaga profesional.

Kemudian pada Undang-Undang Nomor 14 Tahun 2005 tentang Guru dan Dosen pasal 1 ayat 4 disebutkan bahwa profesional adalah pekerjaan atau kegiatan yang dilakukan oleh seseorang dan menjadi sumber penghasilan kehidupan yang memerlukan keahlian, kemahiran, atau kecakapan yang memenuhi standar mutu atau norma tertentu serta memerlukan pendidikan profesi. Pada pasal 2 ayat 1 dan 2 disebutkan bahwa guru mempunyai kedudukan sebagai tenaga profesional pada jenjang pendidikan dasar, pendidikan menengah, dan pendidikan anak usia dini pada jalur pendidikan formal yang diangkat sesuai dengan peraturan perundang-undangan. Pengakuan kedudukan guru sebagai tenaga profesional sebagaimana dimaksud pada ayat (1) dibuktikan dengan sertifikat pendidik. Pada pasal 4 dijelaskan bahwa kedudukan guru sebagai tenaga profesional berfungsi untuk meningkatkan martabat dan peran guru sebagai agen pembelajaran berfungsi untuk meningkatkan mutu pendidikan nasional.

Pada Peraturan Menteri Pendidikan dan Kebudayaan RI Nomor 5 Tahun 2012 tentang Sertifikasi Guru dalam Jabatan pada pasal 2 ayat 1 dijelaskan bahwa sertifikasi dilaksanakan melalui pola; penilaian portofolio, pendidikan dan latihan profesi guru, pemberian sertifikat pendidik secara langsung, atau pendidikan profesi guru. Dan pada 
Peraturan Pemerintah Nomor 74 Tahun 2008 tentang Guru pasal 4 ayat 1 disebutkan bahwa sertifikat pendidik bagi guru diperoleh melalui program pendidikan profesi yang diselenggarakan oleh perguruan tinggi yang memiliki program pengadaan tenaga kependidikan yang terakreditasi, baik yang diselenggarakan oleh pemerintah maupun masyarakat dan ditetapkan oleh pemerintah.

Dalam Undang-Undang Nomor 14 Tahun 2005 tentang Guru dan Dosen dijelaskan bahwa dalam melaksanakan tugas keprofesionalan, guru berhak:

a. Memperoleh penghasilan di atas kebutuhan hidup minimum dan jaminan kesejahteraan sosial;

b. mendapatkan promosi dan penghargaan sesuai dengan tugas dan prestasi kerja;

c. memperoleh perlindungan dalam melaksanakan tugas dan hak atas kekayaan intelektual;

d. memperoleh kesempatan untuk meningkatkan kompetensi; memperoleh dan memanfaatkan sarana dan prasarana pembelajaran untuk menunjang kelancaran tugas keprofesionalan;

e. memiliki kebebasan dalam memberikan penilaian dan ikut menentukan kelulusan, penghargaan, dan/atau sanksi kepada peserta didik sesuai dengan kaidah pendidikan, kode etik guru, dan peraturan perundang-undangan;

f. memperoleh rasa aman dan jaminan keselamatan dalam melaksanakan tugas;

g. memiliki kebebasan untuk berserikat dalam organisasi profesi;

h. memiliki kesempatan untuk berperan dalam penentuan kebijakan pendidikan;

i. memperoleh kesempatan untuk mengembangkan dan meningkatkan kualifikasi akademik dan kompetensi; dan/atau

j. memperoleh pelatihan dan pengembangan profesi dalam bidangnya.

Dalam melaksanakan tugas sebagai tenaga professional guru harus ditunjang dengan kompetensi yang meliputi kompetensi pedagogik, kompetensi kepribadian, kompetensi sosial dan kompetensi profesional.

Tujuan dan manfaat sertifikasi guru seperti yang dijelaskan dalam Suyatno (2007: 2-3) adalah sertifikasi guru bertujuan untuk:

a. menentukan kelayakan guru dalam melaksanakan tugas guru sebagai agen pembelajaran dan mewujudkan tujuan pendidikan nasional. Agen pembelajaran berarti pelaku proses pembelajaran, bukan broker pembelajaran. Bila belum layak, guru perlu mengikuti pendidikan formal tambahan atau pelatihan profesional tertentu

b. meningkatkan proses dan mutu hasil pendidikan. Mutu siswa sebagai hasil proses pendidikan akan sangat ditentukan oleh kecerdasan, minat, dan upaya siswa bersangkutan. Mutu siswa juga ditentukan oleh mutu guru dan mutu proses pembelajaran.

c. Meningkatkan martabat guru. Dengan segala pendidikan formal dan pelatihan yang diikuti , diharapkan guru mamu memberi lebih banyak kepada kemajuan siswa.

d. Meningkatkan profesionalitas guru. Mutu profesional guru ditentukan salah satunya dengan jalan sertifikasi guru.

Sedangkan manfaat sertifikasi guru adalah:

a. Melindungi profesi guru dari praktik-praktik yang tidak kompeten, yang dapat merusak citra profesi guru.

b. Melindungi masyarakat dari praktik-praktik pendidikan yang berkualitas dan tidak profesional.

c. Meningkatkan kesejahteraan guru. Hasil sertifikasi guru dapat dengan mudah digunakan untuk menentukan besarnya imbalan yang pantas diberikan kepada masing-masing guru.

\section{Pengertian Dampak}

Pengertian dampak menurut Kamus Besar Bahasa Indonesia (KBBI) adalah benturan, pengaruh yang mendatangkan akibat baik positif maupun negatif. Pengaruh adalah daya yang ada dan timbul dari sesuatu (orang, benda) yang ikut membentuk watak, kepercayaan atau perbuatan seseorang. Pengaruh adalah suatu keadaan dimana ada hubungan timbal balik atau hubungan sebab akibat antara apa yang mempengaruhi dengan apa yang dipengaruhi (KBBI Online, 2014).

Dalam Soemarwoto (2004: 23) disebutkan bahwa dampak adalah suatu perubahan yang terjadi sebagai akibat suatu aktifitas. Selanjutnya Soemarwoto menjelaskan, aktifitas tersebut bisa bersifat alamiah, berupa kimia, fisik maupun biologi, dapat pula dilakukan oleh manusia berupa analisis dampak lingkungan, pembangunan dan perencanaan. Adapun dampak tersebut dapat bersifat biofisik, sosial, ekonomi dan budaya.

\section{Kualitas Satuan Pendidikan}

Dalam KBBI, kualitas adalah tingkat baik buruknya sesuatu atau kadar, atau sama dengan 
mutu. Dalam Amri (2013: 17) dijelaskan bahwa mutu merupakan keinginan pelanggan, mutu atau kualitas yang tinggi merupakan kunci untuk suatu rasa kebanggaan, tingkat produktivitas dan cermin kemampuan dalam penghasilan. Tujuan mutu harus merupakan produk dan jasa yang dapat memberikan kepuasan bagi pelanggannya.

Mutu atau kualitas pendidikan bukanlah barang akan tetapi layanan, dan mutu harus dapat memenuhi kebutuhan, harapan dan keinginan semua pihak dengan fokus utamanya terletak pada peserta didik. Mutu pendidikan berkembang seirama dengan tuntutan kebutuhan hasil pendidikan yang berkaitan dengan kemajuan ilmu dan teknologi yang melekat pada wujud pengembangan kualitas sumber daya manusia.

Di dalam konteks pendidikan, pengertian kualitas atau mutu dalam hal ini mengacu pada proses pendidikan dan hasil pendidikan. Dari konteks "proses" pendidikan yang berkualitas terlibat berbagai in put (seperti bahan ajar: kognitif, afektif dan, psikomotorik), metodologi (yang bervariasi sesuai dengan kemampuan guru), sarana sekolah, dukungan administrasi dan sarana prasarana dan sumber daya lainnya serta penciptaan suasana yang kondusif. Dengan adanya manajemen sekolah, dukungan kelas berfungsi mensingkronkan berbagai input tersebut atau mensinergikan semua komponen dalam interaksi (proses) belajar mengajar, baik antara guru, siswa dan sarana pendukung di kelas atau di luar kelas, baik dalam konteks kurikuler maupun ekstra-kurikuler, baik dalam lingkungan substansi yang akademis maupun yang non akademis dalam suasana yang mendukung proses belajar pembelajaran.

Dalam Sagala (2007: 170) dijelaskan bahwa peningkatan mutu pendidikan diperoleh melalui dua strategi, yaitu peningkatan mutu pendidikan yang berorientasi akademis untuk memberi dasar minimal dalam perjalanan yang harus ditempuh mencapai mutu pendidikan yang dipersyaratkan oleh tuntutan zaman, dan peningkatan mutu pendidikan yang berorientasi pada keterampilan hidup yang esensial yang dicakupi oleh pendidikan yang berlandasan luas, nyata dan bermakna. Mutu pendidikan tidak hanya ditentukan oleh satuan pendidikan sebagai lembaga pengajaran, tetapi juga disesuaikan dengan apa yang menjadi pandangan dan harapan masyarakat yang cenderung selalu berkembang seiring dengan kemajuan zaman.

Pada Peraturan Pemerintah (PP) No. 19 Tahun 2005 tentang Standar Nasional Pendidikan, ada delapan hal yang harus diperhatikan untuk mewujudkan pendidikan yang berkualitas, yaitu :

a. Standar isi, adalah ruang lingkup materi dan tingkat kompetensi yang dituangkan dalam kriteria tentang kompetensi tamatan, kompetensi bahan kajian, kompetensi mata pelajaran, dan silabus pembelajaran yang harus dipenuhi oleh peserta didik pada jenjang dan jenis pendidikan tertentu.

b. Standar proses, adalah standar nasional pendidikan yang berkaitan dengan pelaksanaan pembelajaran pada satu satuan pendidikan untuk mencapai standar kompetensi lulusan.

c. Standar pendidik dan tenaga kependidikan, adalah kriteria prajabatan dan kelayakan fisik maupun mental, serta pendidikan dalam jabatan.

d. Standar sarana dan prasarana, adalah standar nasional pendidikan yang berkaitan dengan kriteria minimal tentang ruang belajar, tempat berolahraga, tempat beribadah, perpustakaan, laboratorium, bengkel kerja, tempat bermain, tempat berkreasi dan berekreasi, serta sumber belajar lain, yang diperlukan untuk menunjang proses pembelajaran, termasuk penggunaan teknologi informasi dan komunikasi.

e. Standar pengelolaan, adalah standar nasional pendidikan yang berkaitan dengan perencanaan, pelaksanaan, dan pengawasan kegiatan pendidikan pada tingkat satuan pendidikan, kabupaten/kota, provinsi, atau nasional, agar tercapai efisiensi dan efektivitas penyelenggaraan pendidikan.

f. Standar pembiayaan, adalah standar yang mengatur komponen dan besarnya biaya operasi satuan pendidikan yang berlaku selam satu tahun.Standar penilaian pendidikan, adalah standar nasional pendidikan yang berkaitan dengan mekanisme, prosedur, dan instrumen penilaian hasil belajar peserta didik.

g. Standar kompetensi lulusan adalah kriteria mengenai kualifikasi kemampuan lulusan yang mencakup sikap, pengetahuan, dan keterampilan.

Beberapa konsep yang dipergunakan dalam penelitian ini, dioperasionalisasikan sebagai berikut:

1. Dampak dimaksudkan adalah pengaruh atau keterlibatan guru yang telah disertifikasi terhadap peningkatan kualitas madrasah yang dilihat dari beberapa aspek, yaitu pengelolaan madrasah (perencanaan program dan pelaksanaan rencana kerja), peningkatan proses 
pembelajaran, peningkatan kualitas sesama guru, dan pemanfaatn tunjangan sertifikasi.

2. Guru yang disertifikasi dimaksudkan adalah guru yang telah memperoleh sertifikasi, baik melalui jalur pemberian sertifikasi pendidikan secara langsung (PSPL), portofolio, maupun pendidikan dan latihan profesi guru (PLPG).

3. Kualitas madrasah, dimaksudkan tingkat kepemilikan madrasah terhadap komponen pendidikan, dalam penelitian ini terdiri atas lima, yaitu tingkat pengelolaan madrasah, kualitas guru, kualitas proses pembelajaran, kualitas pemanfaatan sarana pembelajaran, dan kualitas evaluasi pembelajaran serta pemanfaatan tunjangan sertifikasi.

4. Pengelolaan madrasah, dimaksudkan kegiatan ketatausahaan yang berkaitan dengan merencanakan kegiatan pendidikan, mengorganisasikan kegiatan pendidikan, melaksanakan kegiatan pendidikan, dan mengevaluasi kegiatan pendidikan.

5. Kualitas guru, dimaksudkan kemampuan guru merancang rencana pembelajaran, melaksanakan pembelajaran dan mengevaluasi pembelajaran.

6. Proses pembelajaran, dimaksudkan kemampuan mengelola kelas seperti penguasaan metode pembelajaran, membangkitkan perhatian dan motivasi siswa, dan penguasaan materi pelajaran.

7. Pemanfaatan sarana pembelajaran, dimaksudkan kemampuan memanfaatkan sarana pembelajaran, serperti alat peraga, komputer, proyektor, internet, dan lain-lain.

\section{METODE PENELITIAN}

Jenis penelitian ini adalah penelitian kuantitatif yang bersifat survei, yaitu metode yang digunakan untuk mendapatkan informasi atau dari sejumlah responden terhadap isu dan topik tertentu dengan menggunakan kuesioner sebagai instrumen utama untuk mengumpulkan data. Penelitian mengamati dampak sertifikasi guru terhadap peningkatan kualitas madrasah. Lebih fokus penelitian menjajaki pengamalan guru yang telah disertikasi dalam berintraksi dengan komunitas madrasah. Komunitas madrasah yang dimaksud adalah sesama guru, tenaga kependidikan, kepala sekolah, dan siswa. Sementara pengalaman yang dimaksud adalah, interaksi akademik/ilmiah (formal maupun non formal) guru yang telah disertifikasi dengan komunitas madrasah sehingga kualitasnya meningkat, sebagai dampak dari status sertifikasi yang diemban. Lokasi Penelitian di Kota Kendari Sulawesi Tenggara.

Instrument pengumpulan data dilakukan dengan kuisioner yaitu memberikan seperangkat pertanyaan atau pernyataan tertulis kepada responden untuk dijawabnya (Sugiyono, 2012:1990). Pertanyaan atau pernyataan ini diberikan melalui angket yang telah disusun berdasarkan pada Permendiknas Nomor 19 Tahun 2007 tentang Standar Pengelolaan Pendidikan pada Satuan Pendidikan Dasar dan Menengah, Permendiknas Nomor 16 Tahun 2007 tentang Standar Kualifikasi Akademik dan Kompetensi Guru, Permendiknas Nomor 41 tahun 2007 tentang Standar Proses untuk Satuan Pendidikan Dasar dan Menengah, serta Permendiknas Nomor 20 Tahun 2007 tentang Standar Penilaian Pendidikan.

Data dikumpulkan dengan menggunakan metode kuantitatif juga didukung dengan hasil wawancara dari beberapa narasumber yang tidak termasuk responden dari sampel penelitian, dan juga dari kajian pustaka. Tingkat dampak guru tersertifikasi terhadap peningkatan kualitas madrasah dikuantifikasi dengan skala likert, sehingga didapatkan data kuantitatif. Kuesioner yang telah dibuat untuk menjaring data penelitian mencakup peran atau ketelibatan guru yang telah disertifikasi dalam perencanaan program madrasah, pelaksanaan rencana kerja madrasah, peningkatan proses pembelajaran, peningkatan kompetensi sesama guru, dan pemanfaatan tunjangan sertifikasi.

Penarikan sampel pada penelitian dilakukan dengan cara purposif kuota random sampling. Purposif yaitu pemilihan sekelompok subyek didasarkan atas ciri atau sifat tertentu yang dipandang mempunyai sangkut paut yang erat kaitannya dengan ciri atau sifat populasi yang ingin diteliti (Tiro, 1999: 83). Penyampelan ini dilakukan dengan memilik satu lokasi penelitian yaitu Kota Kendari (hasil masukan dari pejabat yang berwenang di Kantor Wilayah Kementerian Agama Provinsi Sulawesi Tenggara). Penyampelan kuota adalah metode memilih sampel yang mempunyai ciri tertentu dalam jumlah atau kuota yang diinginkan (Nasution, 1996: 97), sampel yang ditetapkan kuotanya sebanyak 30 responden sesuai dengan porsi yang telah ditentukan berdasarkan pembagian wilayah penelitian di Kawasan Indonesia Timur. Sampel atau responden sebanyak 30 diambil dari hasil random atau acak dari sejumlah guru madrasah aliyah di Kota Kendari yang telah 
tersertifikasi.

Data yang telah terhimpun dianalisis dengan analisis statistik deskriptif, yaitu statistik yang digunakan untuk menganalis data dengan cara mendeskripsikan atau menggambarkan data yang telah terkumpulkan baik dalam bentuk tabel ataupun grafik sebagai mana adanya tampa bermaksud membuat kesimpulan yang berlaku untuk umum atau generalisasi (Sugiyono, 2012: 207). Data yang telah dikuantifikasi dengan skala likert kemudian diolah dengan aplikasi SPPS 16.0 for windows untuk memperoleh gambaran tingkat keterlibatan guru terhadap peningkatan kualitas madrasah.

\section{PEMBAHASAN}

Wilayah Kota Kendari terletak di sebelah Tenggara Pulau Sulawesi. Wilayah daratannya terdapat di daratan Pulau Sulawesi mengelilingi Teluk Kendari. Terdapat satu pulau pada wilayah kota Kendari yang dikenal sebagai Pulau Bungkutoko.
Penduduk kota Kendari berdasarkan Sensus Penduduk 2000 berjumlah 205. 240 jiwa. Ketika dilakukan Survei Penduduk Antarsensus (Supas) pada tahun 2005, diketahui jumlah penduduk kota Kendari meningkat menjadi 226. 056 jiwa. Jumlah Penduduk Tahun 2012 adalah sebesar 304. 862 jiwa. Penduduk tersebut tersebar dengan persebaran yang tidak merata. Pada tahun 2012, sebanyak 14,80 persen penduduk kota Kendari tinggal di wilayah Kendari Barat, hanya 6,68 persen tinggal di Kecamatan baruga, dan selebihnya tersebar pada 8 kecamatan dengan persebaran yang bervariasi. Di samping itu, dilakukan penghitungan kepadatan penduduk pada masing-masing wilayah Kecamatan. Kepadatan penduduk adalah banyaknya penduduk per km persegi. Kadia merupakan kecamatan dengan kepadatan penduduk paling tinggi yaitu sebesar 6.149 jiwa per km2 sedangkan Baruga merupakan kecamatan dengan kepadatan penduduk paling rendah yaitu sebesar 424 jiwa per km2 (Sumber: BPS Provinsi Sulawesi Tenggara)

Jumlah guru dan siswa di Sulawesi Tenggara

\begin{tabular}{lcccccc}
\hline \multicolumn{1}{c}{ KOTA/KAB } & MA & GURU & SISWA & GURU/MA & SISWA/MA & SISWA/ GURU \\
\hline BUTON & 11 & 208 & 1425 & 18.91 & 129.55 & 6.85 \\
MUNA & 14 & 265 & 922 & 18.93 & 65.86 & 3.48 \\
KONAWE & 13 & 193 & 1059 & 14.85 & 81.46 & 5.49 \\
KOLAKA & 16 & 305 & 1617 & 19.06 & 101.06 & 5.30 \\
KONAWE SELATAN & 16 & 262 & 1469 & 16.38 & 91.81 & 5.61 \\
BOMBANA & 7 & 112 & 303 & 16.00 & 43.29 & 2.71 \\
WAKATOBI & 6 & 135 & 755 & 22.50 & 125.83 & 5.59 \\
KOLAKA UTARA & 9 & 126 & 719 & 14.00 & 79.89 & 5.71 \\
BUTON UTARA & 4 & 42 & 132 & 10.50 & 33.00 & 3.14 \\
KONAWE UTARA & 3 & 70 & 150 & 23.33 & 50.00 & 2.14 \\
KOTA KENDARI & 7 & 180 & 1199 & 25.71 & 171.29 & 6.66 \\
KOTA BAU-BAU & 6 & 80 & 315 & 13.33 & 52.50 & 3.94 \\
\hline \multicolumn{2}{c}{ Sumber: Kanwil Kementerian Agama Provisi Sulawesi Tenggara, 2013 } & &
\end{tabular}

\section{Dampak terhadap Perencanaan Program Madrasah}

Keterlibatan responden pada perencanaan program madrasah dilihat dari presentasi keikutsertaan pada penyusunan rumusan visi dan misi madrasah, penyusunan rumusan tujuan madrasah, dan penyusunan rencana kerja madrasah. Dari hasil analisis data diperoleh gambaran bahwa mayoritas responden terlibat langsung yaitu $85,6 \%$ dengan indeks 3.08, ini menunjukkan bahwa sebagian besar responden memiliki perhatian terhadap peningkatan kualitas madrasah terutama pada aspek perumusan tujuan dan rencana kerja madrasah.

Tabel 2. Perencanaan Program Madrasah

\begin{tabular}{lcc}
\hline & \multicolumn{2}{c}{ Dampak } \\
\hline $\begin{array}{l}\text { Perencanaan Program Madrasah } \\
\text { Penyusunan rumusan visi dan misi }\end{array}$ & $83.3 \%$ & 3.07 \\
$\begin{array}{l}\text { madrasah } \\
\text { Penyusunan rumusan tujuan madrasah }\end{array}$ & $86.7 \%$ & 3.03 \\
Penyusunan rencana kerja madrasah & $86.7 \%$ & 3.13 \\
& & \\
Nilai & $85.6 \%$ & 3.08 \\
\hline
\end{tabular}


Jika dilihat dari identitas responden memang rata-rata telah mengalami interaksi yang cukup lama terhadap proses perumusan tujuan dan rencana kerja madrasah, karena sebanyak 19 responden atau 63.3\% telah bertugas sebagai tenaga pendidik pada madrasah aliyah antara 13 sampai 20 tahun.

Keterlibatan responden pada perencanaan program madrasah juga dipengaruhi oleh aktivitas responden pada madrasah, ada beberapa responden hanya menjalankan rutinitas kewajiban sebagai seorang guru yang hanya memperhatikan tanggungjawabnya di kelas pada proses belajar mengajar, dengan beban mengajar 24 jam dalam seminggu yang sudah terpenuhi pada madrasah induk menjadikan guru hanya terfokus pada pemenuhan beban kerja sebagai syarat mendapat sertifikasi.

Berbeda dengan guru yang diberikan tanggungjawab selain mengajar di kelas yaitu pengelolan proses pendidikan pada madrasah seperti wakil kepala madrasah, kepala laboratorium, atau kepala perpustakaan, mereka dituntut untuk terlibat langsung dalam penyusunan program kerja madrasah. Tapi meskipun begitu, keterlibatan guru pada perencanaan program madrasah kembali kepada pribadi guru diri masing-masing, apakah memiliki empati terhadap peningkatan kualitas madrasah atau tidak. Menurut Bapak Abd. Malik (Kepala MAN 2 Kendari) bahwa keterlibatan guru pada peningkatan kualitas madrash tergantung pada karakter masing-masing guru. Ada guru yang tidak merasa memiliki madrasah tetapi hanya numpang untuk memenuhi kewajiban mengajar sehingga guru tersebut akan merasa acuh tak acuh atau tidak terlalu memikirkan terhadap perkembangan madrasah. Lanjut menurut Bapak Abd. Malik bahwa karakter guru sangat dipengaruhi oleh lingkungan rumah tangga, ketika suasana pada lingkungan rumah tangga dibangun dengan nuansa dan pola kekeluargaan yang baik maka akan mempengaruhi sikap guru ketika berada di lingkungan madrasah yaitu menjunjung tinggi nilai-nilai dan normanorma kekeluargaan sehingga akan merasa memiliki madrasah.

Selain itu, guru yang memberikan pengajaran selain di madrasah induk dalam rangka pemenuhan jam mengajar, yaitu pada madrasah yang diadakan oleh masyarakat atau madrasah swasta mempunyai perhatian yang tinggi terhadap peningkatan kualitas madrasah, hal ini dikemukakan oleh Ibu Wa Haya (Kepala MA Darul Mukhlisin) bahwa guru madrasah negeri yang juga mengajar pada madrsah swasta sangat membantu terhadap peningkatan kualitas madrsah. Guru tersebut dapat mentransfer ilmu atau memberi masukan terhadap langkahlangkah peningkatan mutu madrasah seperti yang dilakukan pada madrsah negeri.

Indikator penyusunan visi dan misi madrasah meskipun memberikan signifikansi yang baik terhadap peningkatan kualitas madrasah tetapi mempunyai presentasi keterlibatan guru yang rendah dibanding indikator lainnya yaitu $83.3 \%$. hal ini dilakukan karena penetapan visi dan misi madrasah dilakukan dalam rentang waktu tertentu atau ketika ada kebijakan pergantian pimpinan sehingga intensitas perumusan visi dan misi madrasah tidak terlalu sering.

\section{Dampak terhadap Pelaksanaan Rencana Kerja Madrasah}

Keterlibatan guru terhadap pelaksanaan rencana kerja madrasah menunjukkan nilai signifikansi baik dengan presentasi $77.7 \%$ dan Indeks 2.71. Nilai ini dipengaruhi oleh indikator keterlibatan pada kegiatan kesiswaan dengan presentasi 91.3\%, kegiatan kesiswaan tersebut antara lain adalah penyusunan kriteria dan penerimaan peserta didik setiap tahun ajaran baru, memberikan layanan konseling peserta didik, atau melakukan kegiatan ekstrakurikuler pada peserta didik. Ini dikarenakan setiap tahunnya beberapa guru dilibatkan dalam kepanitiaan tertentu untuk melaksanakan tugas yang salah satunya menerima peserta didik baru.

Tabel 3. Pelaksanaan Rencana Kerja Madrasah

\begin{tabular}{lcc}
\hline & \multicolumn{2}{c}{ Dampak } \\
\hline Pelaksanaan Rencana Kerja Madrasah & & \\
Penyusunan pedoman madrasah & $76.0 \%$ & 2.65 \\
Keterlibatan pada kegiatan kesiswaan & $91.3 \%$ & 3.12 \\
Peningkatan mutu madrasah & $80.0 \%$ & 2.73 \\
Peningkatan mutu pengawasan dan & $63.3 \%$ & 2.35 \\
evaluasi & & \\
Nilai & $77.7 \%$ & 2.71 \\
\hline
\end{tabular}

Pada keterlibatan guru terhadap proses peningkatan mutu pengawasan dan evaluasi hanya memberikan presentasi $63.3 \%$ dengan indeks 2.35 dikarenakan hanya beberapa guru yang mempunyai perhatian terhadap supervisi kinerja madrasah, sebagian beranggapan bahwa supervisi merupakan tanggungjawab pengawas atau tenaga supervisor profesional yang memang mempunyai tugas dan fungsi tersebut yang disediakan oleh pemerintah melalui kementerian pendidikan ataupun kementerian agama. Meskipun supervisi adalah 
untuk kepentingan guru sendiri.

Dalam Sagala (2007: 125) menjelaskan bahwa program supervisi di sekolah adalah program pengembangan guru yang kegiatannya dirancang dengan tema-tema yang berkisar pada penyajian informasi tentang suatu jenis pendekatan, membantu guru memahami informasi, membantu guru mengaplikasikan pemahaman pengajaran, dan membantu guru memahami tingkat pengetahuan serta integrasi nilai dan sikap. Supervisi pendidikan meliputi (1) menilai dan membina guru dan seluruh staf sekolah dalam bidang teknis edukatif dan administratif, (2) usaha mencari, mengembangkan dan mempergunakan berbagai metode belajar mengajar yang lebih baik dan sesuai untuk mengembangkan aspek kognitif, afektif, dan psikomotorik peserta didik, (3) mengusahakan mengembangkan kerjasama yang baik antara guru, kepala sekolah, peserta didik dan pegawai sekolah, (4) mengembangkan kerjasama antara kelompok kerja guru, musyawarah guru mata pelajaran, kelompok kerja kepala sekolah dan musyawarah kepala sekolah, dan (5) upaya mempertinggi kualitas guru dan kepala sekolah melalui penataran, orientasi dan up-grading.

\section{Dampak terhadap Peningkatan Proses Pembelajaran}

Keterlibatan guru pada peningkatan proses pembelajaran memberikan dampak yang sangat signifikan terhadap peningkatan kualitas madrasah yaitu $98.6 \%$ dengan indeks 3.75, hampir semua indikator memberikan presentasi $100 \%$, hanya indikator kegiatan pada madrasah induk yang memberikan presentasi 90\% karena memang tidak semua responden yang melakukan atau memberikan pengajaran total pada madrasah induk.

Dampak dengan presentasi ketelibatan yang tinggi tersebut tidak terlepas dari ketentuan bahwa proses pembelajaran merupakan bagian fungsi dan tugas guru profesional. Menurut Rostiyah (dalam Shoimin, 2013: 32) bahwa fungsi dan tugas guru profesional antara lain:

1. Menyerahkan kebudayaan kepada anak didik berupa kepandaian, kecakapan dan pengalaman-pengalaman.

2. Membentuk kepribadian anak yang harmonis sesuai cita-cita dan dasar negara kita Pancasila.

3. Menyiapkan anak-anak menjadi warga negara yang baik sesuai dengan Undang-Undang.

4. Sebagai prantara dalam belajar.

5. Guru adalah sebagai pembimbing untuk membawa anak didik ke arah kedewasaan.

Pendidik tidak maha kuasa, tidak dapat membentuk anak menurut kehendak hatinya.

6. Guru sebagai penghubung antara sekolah dan masyarakat.

7. Sebagai penegak disiplin, guru menjadi contoh dalam segala hal, tata tertib dapat berjalan apabila guru menjalaninya terlebih dahulu.

8. Sebagai administrator dan manajer serta sebagai perencana kurikulum.

9. Guru sebagai pemimpin.

10. Guru sebagai sponsor dalam kegiatan anakanak.

Tabel 4. Peningkatan Proses Pembelajaran

\begin{tabular}{lcc}
\hline & \multicolumn{2}{c}{ Dampak } \\
\hline Peningkatan Proses Pembelajaran & & \\
Memulai pelajaran & $100 \%$ & 3.88 \\
Kegiatan eksplorasi & $100 \%$ & 3.94 \\
Penyampaian materi pelajaran inti & $100 \%$ & 3.93 \\
Sikap mengajar & $100 \%$ & 3.97 \\
Menutup pelajaran & $100 \%$ & 3.88 \\
Kegiatan pada madrasah induk & $90 \%$ & 2.77 \\
Disiplin & $100 \%$ & 3.91 \\
Nilai & $98.6 \%$ & 3.75 \\
\hline
\end{tabular}

Selain fungsi dan tugas guru, peran guru dalam kelas juga sangat menentukan proses pembelajaran dapat berjalan dengan baik dan sesuai dengan tujuan yang diharapkan bersama. Menurut Doyle (dalam Danim, 2010: 185) peran utama guru kelas adalah menciptakan keteraturan (establishing order) dan memfasilitasi proses belajar (facilitating learning). Keteraturan yang dimaksud di sini mencakup hal-hal yang terkait langsung atau tidak langsung dengan proses pembelajaran seperti; tata letak tempat duduk, disiplin siswa dalam kelas, interaksi siswa dengan sesamanya, interaksi siswa dengan guru, jam masuk dan keluar untuk setiap sesi mata pelajaran, pengelolaan sumber belajar, pengelolaan bahan ajar, prosedur dan sistem yang mendukung sistem pembelajaran, dan lingkungan belajar.

Dalam Nurdin (2005: 79) dijelaskan bahwa hal-hal yang sangat erat kaitannya dengan tugas mengajar di kelas (profesional), terdapat sepuluh kompetensi atau kemampuan dasar yang harus dimiliki oleh guru, yaitu; menguasai bahan yang akan diajarkan, mengelola program belajar mengajar, mengelola kelas, menggunakan media/ sumber belajar, menguasai landasan-landasan kependidikan, mengelola interaksi belajar mengajar, menilai prestasi siswa, mengenal fungsi dan 
program bimbingan dan penyuluhan, mengenal dan menyelenggarakan administrasi sekolah, dan memahami prinsip-prinsip dan menafsirkan hasilhasil penelitian.

\section{Dampak terhadap Peningkatan Kompetensi Sesama Guru}

Peningkatan kompetensi sesama guru memiliki presetansi dan indeks yang sangat signifikan terhadap peningkatan kualitas madrasah, yaitu $96.0 \%$ dan 3.50, hal ini disebabkan karena memang untuk menjadi guru yang profesional dipersyaratkan memiliki kompetensi dengan standarisasi yang telah ditetapkan oleh pemerintah.

Berdasarkan kode etik guru, guru wajib menjaga hubungan yang baik dengan sesama guru, baik hubungan formal yaitu hubungan yang bersifat kedinasan maupun hubungan kekeluargaan yaitu saling menghormati dan menjunjung tinggi sikap toleransi agar persaingan yang sehat diantara guru dapat sering ditumbuhkan dalam rangka memicu semangat guru untuk meningkatkan kompetesinya masing-masing.

Peningkatan kompetensi sesam guru sangat dipengaruhi oleh aspek kompetensi profesional karena memberikan dampak yang sangat signifikan yaitu $100 \%$ dengan indeks 3.61, salah satu indikator penyebabnya adalah intensitas guru berdiskusi tentang penyusunan materi pelajaran, cara mengembangkan profesionalitas guru, dan pemanfaatan teknologi informasi dan komunikasi pembelajaran.

Tabel 5. Peningkatan Kompetensi sesama Guru

\begin{tabular}{lcc}
\hline & \multicolumn{2}{c}{ Dampak } \\
\hline Peningkatan Kompetensi Sesama Guru & & \\
Kompetensi pedagogik & $94.0 \%$ & 3.26 \\
Kompetensi sosial & $96.7 \%$ & 3.60 \\
Kompetensi kepribadian & $93.3 \%$ & 3.52 \\
Kompetensi profesional & $100 \%$ & 3.61 \\
Nilai & $96.0 \%$ & 3.50 \\
\hline
\end{tabular}

Peningkatan kompetensi guru menjadi hal mutlak dalam proses peningkatan kualitas madrasah. Dalam Peraturan Pemerintah Nomor 74 Tahun 2008 tentang Guru dijelaskan bahwa guru harus memiliki kompetensi pedagogik, kompetensi kepribadian, kompetensi sosial, dan kompetensi profesional.

Kompetensi pedagogik, merupakan kemampuan Guru dalam pengelolaan pembelajaran peserta didik yang sekurangkurangnya meliputi; pemahaman wawasan atau landasan kependidikan, pemahaman terhadap peserta didik, pengembangan kurikulum atau silabus, perancangan pembelajaran, pelaksanaan pembelajaran yang mendidik dan dialogis, pemanfaatan teknologi pembelajaran, evaluasi hasil belajar, dan pengembangan peserta didik untuk mengaktualisasikan berbagai potensi yang dimilikinya.

Kompetensi kepribadian, sekurangkurangnya mencakup kepribadian yang beriman dan bertakwa, berakhlak mulia, arif dan bijaksana, demokratis, mantap, berwibawa, stabil, dewasa, jujur, sportif, menjadi teladan bagi peserta didik dan masyarakat, secara obyektif mengevaluasi kinerja sendiri, dan mengembangkan diri secara mandiri dan berkelanjutan.

Kompetensi sosial, merupakan kemampuan guru sebagai bagian dari masyarakat yang sekurang-kurangnya meliputi kompetensi untuk berkomunikasi lisan, tulis, dan/atau isyarat secara santun, menggunakan teknologi komunikasi dan informasi secara fungsional, bergaul secara efektif dengan peserta didik, sesama pendidik, tenaga kependidikan, pimpinan satuan pendidikan, orang tua atau wali peserta didik, bergaul secara santun dengan masyarakat sekitar dengan mengindahkan norma serta sistem nilai yang berlaku, dan menerapkan prinsip persaudaraan sejati dan semangat kebersamaan.

Kompetensi profesional, merupakan kemampuan guru dalam menguasai pengetahuan bidang ilmu pengetahuan, teknologi, dan/atau seni dan budaya yang diampunya yang sekurangkurangnya meliputi penguasaan; materi pelajaran secara luas dan mendalam sesuai dengan standar isi program satuan pendidikan, mata pelajaran, dan/ atau kelompok mata pelajaran yang akan diampu, dan konsep dan metode disiplin keilmuan, teknologi, atau seni yang relevan, yang secara konseptual menaungi atau koheren dengan program satuan pendidikan, mata pelajaran, dan/atau kelompok mata pelajaran yang akan diampu.

\section{Dampak terhadap Pemanfaatan Tunjangan Sertifikasi}

Pemanfaatan tunjangan sertifikasi tidak terlalu memberikan dampak yang signifikan terhadap peningkatan kualitas madrasah yaitu hanya $36.0 \%$ dengan indeks 1.66 , hal ini dipengaruhi sebagian besar responden memanfaatkan tunjangan sertifikasi untuk kepentingan pribadi seperti menunaikan ibadah haji, membeli busana, tas, atau sepatu, membeli perhiasan, dan untuk kepentingan 
keluarga seperti membeli atau kredit kendaraan bermotor, membeli/kredit/renovasi rumah, atau membeli prabot rumah tangga. Pemanfaatan tunjangan sertifikasi untuk kepentingan pribadi dan kepentingan keluarga dianggap tidak berdampak pada peningkatan kualitas madrasah karena tidak berhubungan langsung terhadap proses peningkatan kualitas madrasah. Jadi ketika responden memilih kedua indikator tersebut maka tidak presentasikan atau diberi indeks 1.00, kecuali pada pemanfaatan tunjangan sertifikasi untuk kepentingan pribadi ada sejumlah responden yang tidak memilih atau tidak memberikan tanggapan terhadap item-item untuk kepentingan pribadi, yaitu sebanyak 5 orang responden atau $16.7 \%$.

Hal ini dimaklumi adanya, karena kalau merujuk pada teori hirarki kebutuhan Abraham Maslow, rata-rata tingkat kebutuhan komponen masyarakat di Negara berkembang sebagian besar masih pada tarafkebutuhan fisiologis atau kebutuhan dasar yaitu kebutuhan berupa kelengkapan pangan dan sandang dan pada taraf kebutuhan pada rasa aman, belum pada tingkat kebutuhan aktualisasi diri.

Tabel 6. Pemanfaatan Tunjangan Sertifikasi

\begin{tabular}{lcc}
\hline & \multicolumn{2}{c}{ Dampak } \\
\hline Pemanfaatan Tunjangan Sertifikasi & & \\
Kepentingan pribadi & $16.7 \%$ & 1.00 \\
Kepentingan keluarga & $0.0 \%$ & 1.00 \\
Kepentingan peningkatan profesi & $96.7 \%$ & 1.50 \\
Kepentingan sarana pembelajaran & $90.0 \%$ & 3.13 \\
Nilai & $36.0 \%$ & 1.66 \\
\hline
\end{tabular}

Pada pemanfaatan tunjangan sertifikasi untuk peningkatan profesi seperti melanjutkan pendidikan ke strata berikutnya, melakukan penelitian, mengikuti kursus komputer atau bahasa, dan untuk kepentingan sarana pembelajaran seperti membeli komputer, membeli sarana internet, membeli buku/ literatur, atau membeli kamera atau media visual, memberikan dampak yang signifikan terhadap peningkatan kualitas madrasah yaitu $96.7 \%$ dan 90.0\%. Pemanfaatan tunjangan sertifikasi untuk peningkatan profesi dan pemenuhan fasilitas sarana belajar mengajar memang sudah sesuai dengan salah satu tujuan sertifikasi guru yaitu meningkatkan kompetensi guru dan kesejateraan guru.

Sertifikasi guru merupakan upaya pemerintah dalam meningkatkan mutu guru sehingga pembelajaran di sekolah juga akan berkualitas. Dengan asumsi, peningkatan mutu guru akan dibarengi dengan peningkatan kesejahteraan guru sehingga diharapkan dapat meningkatkan mutu pembelajaran dan mutu pendidikan secara berkelanjutan. Peningkatan kesejahteraan guru dalam bentuk tunjangan profesi sebesar satu kali gaji pokok bagi guru yang telah memiliki sertifikat pendidik, bertujuan untuk menentukan kelayakan guru dalam melaksanakan tugas sebagai agen pembelajaran dan mewujudkan tujuan pendidikan nasional, meningkatkan proses dan mutu hasil pendidikan, meningkatkan martabat guru, dan meningkatkan profesionalisme guru (Shoimin, 2013: 79).

Pemanfaatan tunjangan sertifikasi guru sebagain besar masih digunakan untuk kepentingan pribadi dan kepentingan keluarga, hal ini diungkapkan oleh bapak Samsuri, M.Pd (Kepala Bidang Pendidikan Madrasah Kantor Wilayah Kementerian Agama Sulawesi Tenggara), bahwa sertifikasi guru belum sesuai harapan terutama peningkatan kompetensinya, guru belum memperlihatkan dampak dari sertifikasi yang telah didapatkan baik terhadap peningkatan pembelajaran maupun pada satuan pendidikan secara umum.

Hal senada dikemukakan oleh Ibu Aspa, S.Pd.I (Kasubbag TU MTsN 1 Kendari) bahwa dampak secara umum sertifikasi biasa-biasa saja, sepertinya tidak ada perubahan terhadap kompetensi guru baik kompetensi pedagogik, kompetensi kepribadian, kompetensi profesional maupun kompetensi sosial. Jelas yang nyata berdampak adalah pada kesejahteraan guru yang sudah mendapat sertifikasi yaitu sudah bisa memaksimalkan transportasi dari tempat tinggal ke sekolah/madrasah, juga media atau perangkat pengajaran sudah bisa terpenuhi seperti notebook atau laptop.

Berikutnya juga disampaikan oleh beberapa Kepala Madrasah Tsanawiyah yang ada di Kota Kendari seperti yang disampaikan oleh Bapak Ismail Kadir dari MTs Pesri dan Bapak Syaifuddin dari MTs DDI bahwa dampak sertifikasi yang nyata adalah hanya dari kesejahteraan guru sehingga bisa memenuhikebutuhan pendukung pengajaran seperti mengadakan laptop yang dapat digunakan untuk mengakses informasi-informasi mengenai dunia pendidikan termasuk perkembangan pendidikan baik dalam aspek regulasi-regulasi terbaru tentang pendidikan, metode-metode pembelajaran, strategi-strategi pembelajaran maupun hal-hal yang berhubungan dengan pendekatan yang dilakukan kepada peserta didik untuk meningkatkan motivasi belajar termasuk psokilogi pendidikan. 


\section{PENUTUP}

Dari hasil penelitian, dampak sertifikasi guru terhadap peningkatan kualitas madrasah jika dilihat dari keterlibatan guru yang sudah tersertifikasi terhadap aspek-aspek yang mempengaruhi kualitas madrasah mempunyai presentasi keterlibatan yang tinggi, meskipun masih ada beberapa guru berpendapat bahwa dampak sertifikasi tidak terlalu mempengaruhi kompetensi guru, banyak guru yang merasa bahwa kompetensi yang dimiliki tidak terlalu berbeda sebelum dan sesudah mendapat sertifikat pendidik. Yang sangat jelas memberikan dampak adalah dari segi kesejahteraan guru karena adanya tunjangan sertifikasi, kedisiplinan guru yang tinggi karena harus memenuhi 24 jam mengajar setiap minggunya, serta metode-metode pengajaran yang kontemporer yang didapatkan dari hasil pendidikan dan pelatihan guru untuk sertifikasi.

Peningkatan kompentensi guru banyak dilakukan oleh usaha guru sendiri misalnya dengan mengadakan sarana atau media (laptop dan internet) untuk mendapatkan informasi terkini yang berhubungan dengan kompetensi dan profesionalisme guru.

Harus segara diterapkan regulasi yang mengatur sertifikasi guru melalui pendidikan profesi guru (PPG) karena sebelum terjun ke masyarakat sebagai agen pembelajaran sudah dibekali dengan kompetensi yang sesuai dengan standard dan kualifikasi yang dipersyaratkan.

Perlu diadakan konsolidasi guru tersertifikasi baik melalui workshop ataupun pertemuanpertemuan ilmiah dalam rangka mencari langkahlangkah strategis efektif, dan efesien untuk peningkatan kompetensi guru.

Perlunya diadakan pendidikan dan pelatihan guru dalam rangka peningkatan kompetensi dan profesionalisme guru meskipun bukan untuk tujuan atau yang berhubungan dengan sertifikasi. Juga perlunya peningkatan kesejahteraan guru melalui tunjangan meskipun bukan dari dampak telah memperoleh sertifikat pendidik, artinya pemberian tunjangan profesi guru sudah selayaknya diberikan kepada semua guru meskipun belum mendapatkan sertifikasi.

\section{UCAPAN TERIMA KASIH}

Penelitian ini dapat selesai berkat bantuan beberapa pihak, olehnya penulis mengucapkan terima kasih kepada Bapak Kepala Kantor Kementerian Agama Kota Kendari, Kepala MAN 1 dan MAN 2 Kota Kendari, Kepala MA Darul
Mukhlisin Kota Kendari, Guru-Guru MA yang ada di Kota Kendari yang penulis tidak dapat sebutkan satu persatu. Dan juga kepada Bapak Kepala Balai Litbang Agama Makassar yang telah memberikan kebijakan sehingga penelitian ini dapat terlaksana.

\section{DAFTAR PUSTAKA}

Amri, Sofan. 2013. Peningkatan Mutu Pendidikan Sekolah Dasar dan Menengah; Dalam Teori dan Praktek. Jakarta: Prestasi Pustakarya.

Danim, Sudarwan. 2010. Inovasi Pendidikan. Dalam Upaya Peningkatan Profesionalisme Tenaga Kependidikan. Bandung: Pustaka Setia.

Kementerian Pendidikan dan Kebudayaan. Sertifikasi Guru dalam Jabatan. Buku 4 Rambu-Rambu Pelaksanaan Pendidikan dan Latihan Profesi Guru (PLPG). 2013. Badan Pengembangan Sumber Daya Manusia Pendidikan Kebudayaan dan Penjamin Mutu Pendidikan.

Mulyasa, E. 2012. Standar Kompetensi dan Sertifikasi Guru. Bandung: Remaja Rosdakarya.

Nasution, S. 1996. Metode Research; Penelitian Ilmiah. Jakarta: Bumi Aksara.

Nurdin, Syafruddin. 2005. Guru Profesional dan Implementasi Kurikulum. Jakarta: Quantum Teaching.

Peraturan Pemerintah Nomor 19 Tahun 2005 tentang Standar Nasional Pendidikan.

Peraturan Pemerintah Nomor 74 Tahun 2008 tentang Guru.

Sagala, Syaiful. 2007. Manajemen Strategik Dalam Peningkatan Mutu. Bandung: Pendidikan. Alfabeta.

Shoimin, Aris. 2013. Excellent Teacher, Meningkatkan Profesionalisme Guru Pasca Sertifikasi. Semarang: Dahara Prize.

Soemarwoto, Otto. 2004. Ekologi, Lingkungan Hidup dan Pembangunan. Jakarta: Djambatan.

Sugiyono. Metode Penelitian Pendidikan. 2012. Pendekatan Kuantitatif, Kualitatif, dan R\&D. Bandung: Alfabeta.

Suprihatiningrum, Jamil. 2013. Guru Profesional: Pedoman Kinerja, Kualifikasi dan Kompetensi Guru. Yogyakarta: Ar Ruzz Media.

Suyatno. 2007. Panduan Sertifikasi Guru. Jakarta: Indeks.

Tiro, Muhammad Arif. 1999. Dasar-Dasar Statistika. Makassar. State University of Makassar Press.

Undang-Undang Nomor 14 Tahun 2005 tentang Guru dan Dosen.

Undang-Undang Nomor 20 Tahun 2003 tentang Sistem Pendidikan Nasional. 